\title{
GC-MS Analysis of $\mathrm{N}$-Hexane Extracts of Turkish Ankyropetalum Species
}

\section{Türkiye'de Yetişen Ankyropetalum Türlerinin N-Hegzan Özütlerinin GC-MS Analizi}

\author{
Research Article
}

\section{Gamze Koz and Ömer Koz*}

Department of Chemistry, Faculty of Natural Sciences, Architecture and Engineering, Bursa Technical University, Bursa, Turkey.

\section{A B S TR AC T}

The chemical constituents of crude n-hexane extracts of three Ankyropetalum species, Ankyropetalum gypsophiloides Fenzl, Ankyropetalum arsusianum Kotschy Ex Boiss. and Ankyropetalum reuteri Boiss. Et Hausskn. from Turkey was determined using GC-MS analysis. Thirty three components were identified with Palmitic Acid Methyl Ester and Oleic Acid Methyl Ester as the most abundant components.

\section{Key Words}

Ankyropetalum gypsophiloides Fenzl, Ankyropetalum arsusianum Kotschy Ex Boiss., Ankyropetalum reuteri Boiss. Et Hausskn., GC-MS analysis.

\section{öz}

\footnotetext{
Türkiye'de yetişen üç Ankyropetalum türü olan Ankyropetalum gypsophiloides Fenzl, Ankyropetalum arsusianum Kotschy Ex Boiss. ve Ankyropetalum reuteri Boiss. Et Hausskn. bitkilerinin ham n-hekzan özütlerinin içerdiği kimyasal bileşenler GC-MS (Gaz kromatografisi-Kütle spektrometresi) ile belirlendi. Tanımlanan otuz iki bileşen arasında palmitik asit metil esteri ve oleik asit metil esterinin en yüksek orana sahip olduğu saptandı.
}

\section{Anahtar Kelimeler}

Ankyropetalum gypsophiloides Fenzl, Ankyropetalum arsusianum, Kotschy Ex Boiss., Ankyropetalum reuteri Boiss. Et Hausskn., GC-MS analizi.

Article History: Received: Mar 19, 2017; Revised: Jul 11, 2017; Accepted: Oct 9, 2017; Available Online: Dec $25,2017$. DOI: 10.15671/HJBC.2018.177

Correspondence to: Ö. Koz, Dep. of Chem., Architecture and Engineering, Bursa Technical University, Bursa, Turkey. 


\section{INTRODUCTION}

$\Delta$ nkyropetalum Fenzl genus has 4 species in the world and 3 of them are grown in Turkey. One of them is endemic and the others are rare. The genus is essentially pervasive in south-west Asia including Turkey. Regarding the phytogeography the genus grows in the south-east part of Turkey; that is in Irano-Turanian and Mediterranean regions $[1,2]$. The species belonging to the Ankyropetalum genus in Turkey are Ankyropetalum gypsophiloides Fenzl, Ankyropetalum arsusianum Kotschy Ex Boiss. and Ankyropetalum reuteri Boiss. Et Hausskn. (endemic). The roots of Ankyropetalum species are economically important and used as food additive as a result of their rich saponin content [3]. Furthermore, saponins obtained from Ankyropetalum species are used as adjuvant in some vaccines and fire extinguishers $[4,5]$. Despite the economic importance and wide area of application, there are no phytochemical studies reported on these species.

As a part of our ongoing project on the analysis of chemical constituents of Ankyropetalum species, we investigated the content of $\mathrm{n}$-hexane extracts of A. gypsophiloides, A. arsusianum and $A$. reuteri by GC-MS.

\section{MATERIALS and METHODS}

\section{Plant Material}

Plant materials were collected from different locations as $A$. gypsophilides from Bozova, Işınlı, Şanlıurfa, A. arsusianum from Osmaniye-Ceyhan and $A$. reuteri from Nurdağı, Gaziantep in June 2014.

\section{Sample Preperation}

Air-dried aerial parts of the plant materials were extracted with n-hexane using soxhalet extractor. The oily mixtures were derived to their methyl esters using trans-esterification process of the International Union of Pure and Applied Chemistry [6]. According to this process, dried hexane extracts were dissolved in heptane and then extracted with $2 \mathrm{M}$ methanolic $\mathrm{KOH}$ at room temperature for $30 \mathrm{~s}$. The upper phases were analyzed by GC-MS systems.

\section{Gas Chromatography/Mass Spectrometry (GC-MS) Analysis}

The methyl esters of fatty acids were analyzed by Agilent 7890 A and Agilent 5975C inert XL MSD (mass selective detector) combined system with HP-5MS column $(30 \mathrm{~m} \times 0.25 \mathrm{~mm} \times 0.25 \mu \mathrm{m})$. Pure helium gas (99.999\%) was used as a carrier gas at a constant flow rate of $1 \mathrm{~mL} / \mathrm{min}$. The oven temperature was programmed as $60^{\circ} \mathrm{C}$ for $5 \mathrm{~min}$. then $5^{\circ} \mathrm{C} / \mathrm{min}$ to $220^{\circ} \mathrm{C}$ and kept constant for 5 min. The sample (in heptane) of $1 \mu \mathrm{L}$ was injected in the split mode with a split ration 20:1. The component identification was carried out using spectrometric electronic libraries (WILEY and NIST).

\section{RESULTS and DISCUSSION}

The compositions of the chemical compounds isolated from three species of Ankyropetalum are shown in Table 1.

The major chemical compounds in $\mathrm{n}$-hexane crude extracts of $A$. gypsophilides, $A$. arsusianum and $A$. reuteri were found as Palmitic Acid Methyl Ester (24.88\%), Oleic Acid Methyl Ester (21.62\% and $20.75 \%$ ) respectively. Linoleic Acid Methyl Ester $\left(\mathrm{LA}^{-} \omega-6\right)$ was also determined as $9.30 \%$ in $A$. arsusianum and $12.81 \%$ in $A$. reuteri.

\section{ACKNOWLEDGEMENTS}

Harran University, Department of Chemistry and Biology were gratefully acknowledged for providing the plant material. Undergraduate students Onur Çakır, Sedat Kale and Zafer Bulut are also gratefully acknowledged for their support in the laboratory. 
Table 1. The identified chemical compounds in n-hexane crude extracts of Ankyropetalum species.

\begin{tabular}{|c|c|c|c|c|}
\hline \multirow[t]{2}{*}{$\mathrm{RI}$} & \multirow[t]{2}{*}{ Compound } & \multicolumn{3}{|c|}{ Composition (\%) } \\
\hline & & A. gypsophilides & A. arsusianum & A. reuteri \\
\hline 8.89 & Tetradecane & 0.33 & - & - \\
\hline 11.87 & 2,6-Di-tert-butyl-4-cresol & 0.89 & 1.43 & 0.73 \\
\hline 12.05 & Lauric acid methyl ester & 2.23 & 1.79 & 1.40 \\
\hline 12.37 & $\begin{array}{c}\text { 5,6,7,7a-Tetrahydro-4,4,7-trimethyl-2(4H)- } \\
\text { Benzofuranone }\end{array}$ & - & 0.24 & - \\
\hline 16.21 & Heptadecane & 0.27 & - & - \\
\hline 16.79 & Myristic acid methyl ester & 5.55 & 3.10 & 3.16 \\
\hline 18.40 & Octadecane & 0.26 & - & - \\
\hline 18.95 & Pentadecanoic acid methyl ester & 0.47 & 0.46 & 0.40 \\
\hline 19.36 & Hexahydrofarnesyl acetone & 3.19 & 1.50 & 1.65 \\
\hline 20.06 & 1-Nonadecanol & 1.33 & 0.27 & 0.40 \\
\hline 20.47 & Nonadecane & 0.33 & - & - \\
\hline 20.53 & 7-Hexadecenoic acid methyl ester & - & - & 0.26 \\
\hline 20.89 & Farnesyl acetate 3 & 0.42 & - & - \\
\hline 21.01 & Palmitic acid methyl ester & 24.88 & 19.61 & 17.24 \\
\hline 22.44 & Eicosane (icosane) & 0.26 & 0.22 & - \\
\hline 22.95 & 14-Methyl-hexadecanoic acid methyl ester & 0.44 & 0.28 & 0.46 \\
\hline 23.55 & 2-Cis-9-octadecenyloxyethanol & - & 0.36 & 0.29 \\
\hline 23.55 & Oleyl alcohol, methyl ether & 1.36 & - & - \\
\hline 24.00 & 1-Octadecene & 1.45 & 0.33 & - \\
\hline 24.23 & Linoleic acid methyl ester & 4.33 & 9.30 & 12.81 \\
\hline 24.35 & Oleic acid methyl ester & 17.65 & 21.62 & 20.75 \\
\hline 24.45 & Elaidic acid methyl ester & 1.18 & 1.19 & 1.08 \\
\hline 24.56 & Phytol & 6.44 & 8.58 & 5.11 \\
\hline 24.82 & Stearic acid methyl ester & 3.31 & 3.60 & 3.83 \\
\hline 25.38 & Lignoceryl alcohol & - & 0.92 & 0.96 \\
\hline 25.93 & Octadecane & 4.43 & - & - \\
\hline 25.94 & Pentacosane & - & - & 1.04 \\
\hline 27.46 & Behenic acid methyl ester & 2.42 & 3.38 & 3.68 \\
\hline 28.14 & 1-Octadecanol & - & 0.47 & 0.60 \\
\hline 28.49 & Octadecane & - & - & 0.32 \\
\hline 28.92 & 1-Heptacosanol & - & - & 3.32 \\
\hline 29.28 & Arachidic acid methyl ester & 4.10 & 4.15 & 9.29 \\
\hline
\end{tabular}

\section{References}

1. F.U. Afifi, B. Abu-Irmaileh, Herbal medicine in jordan with special emphasis on less commonly used medicinal herbs, J. Ethnopharm., 72 (2000) 101-110.

2. H. Özçelik, F. Özgökçe, Taxonomic contributions to Genus Gypsophila L. (Caryophyllaceae) from East Anatolia (Turkey), IVth Plant Life in Southwest and Central Asia (Ed. M. Öztürk, Ö. Seçmen and G. Görk), Ege University Press, İzmir, Turkey, (1995) 195-209.

3. T. Baytop, Türkiye'de Bitkiler ile Tedavi (Theraphy with medicinal plants in Turkey), Nobel Tıp press, İstanbul, (1984) 190-191.
4. M. Öztürk, H. Özçelik, Useful Plants of East Anatolia, SisKAV Publications, Semih Ofset and Press, Ankara, (1991).

5. M. Korkmaz, H. Özçelik, Economic importance of Gypsophila L., Ankyropetalum Fenzl and Saponaria L. (Caryophyllaceae) taxa of Turkey, Afr. J. Biotechnol, 10 (2011) 9533-9541.

6. C. Paquat, A. Hautfenne, International Union of Pure and Applied Chemistry, Blackwell Scientific Publications, London, (1992). 
